\title{
Anthelmintic activity of Tunisian chamomile (Matricaria recutita L.) against Haemonchus contortus
}

\author{
S. Hajaji ${ }^{1,2 *}$, D. Alimi ${ }^{1,2}$, M.A. Jabri ${ }^{2,3}$, S. Abuseir ${ }^{4}$, M. Gharbi ${ }^{1}$ and \\ H. Akkari ${ }^{1}$
}

${ }^{1}$ Laboratoire de Parasitologie, Université de la Manouba, École Nationale de Médecine Vétérinaire de Sidi thabet, 2020, Tunisia: ${ }^{2}$ Faculté des sciences de Bizerte, Université de Carthage, 7021, Zarzouna, Tunisia:

${ }^{3}$ Laboratoire de Physiologie Intégrée, Faculté des Sciences de Bizerte, Département des Sciences de la Vie, 7021 Zarzouna, Tunisia: ${ }^{4}$ Faculty of Agriculture and Veterinary Medicine, An-Najah National University, PO Box 7, Nablus, Palestine

(Received 17 January 2017; Accepted 12 April 2017; First published online 8 May 2017)

\begin{abstract}
The chemical treatment of gastrointestinal parasitic diseases has been undermined by increasing resistance and high toxicity. There is an urgent need to search for alternative natural sources for the treatment of such parasites. In this respect, the present study aims to quantify phenolic compounds of chamomile (Matricaria recutita L.) and to study their in vitro anti-oxidant and anthelmintic activities in solvents with increasing polarity. In vitro determination of anti-oxidant capacity was carried out using 2,2-diphenyl-1-picrylhydrazyl (DPPH) and 2,2-azino-bis(3-ethylbenzthiazoline-6-sulphonic acid) (ABTS) radical cation methods. In vitro anthelmintic activity was investigated on egg-hatching inhibition and loss of motility of adult worms of Haemonchus contortus from sheep. The results showed that methanolic and aqueous extracts contain more total polyphenols, total flavonoids and condensed tannins than chloroformic and hexanic extracts. ABTS and $\mathrm{DPPH}$ assays showed that methanolic extracts had the highest anti-oxidant potency $\left(\mathrm{IC}_{50}=1.19 \mu \mathrm{g} / \mathrm{ml}\right.$ and $1.18 \mu \mathrm{g} / \mathrm{ml}$, respectively). In vitro anthelmintic activity showed that both methanolic $\left(\mathrm{IC}_{50}=1.559 \mathrm{mg} / \mathrm{ml}\right)$ and aqueous $\left(\mathrm{IC}_{50}=2.559 \mathrm{mg} / \mathrm{ml}\right)$ extracts had the greatest effect on egg hatching and motility of worms $(100 \%$ after $8 \mathrm{~h}$ post exposure at $8 \mathrm{mg} / \mathrm{ml})$. A significant and positive correlation between DPPH and ABTS tests was observed for all tested extracts. Therefore, total phenolic, total flavonoid and condensed tannin values were correlated with $\mathrm{IC}_{50}$ from both ABTS and DPPH, and with inhibition of egg hatching. To our knowledge, this report is the first of its kind to deal with in vitro anthelmintic activities of chamomile extracts.
\end{abstract}

*Fax: +21671 537044

E-mail: soumayahajjaji86@gmail.com

\section{Introduction}

Ovine parasitic infections by gastrointestinal helminths have an enormous economic impact in terms of morbidity, mortality, decreased production of milk, meat and wool (Chartier \& Hoste, 1994; Akhtar et al., 2000; 
Githiori et al., 2006). Among the dominant species of nematodes of sheep, Haemonchus contortus causes severe damage to animal health because of its high prevalence and its pathogenicity, related to its haematophagous habits (Angulo-Cubillán et al., 2010; Hoberg et al., 2010; Besier et al., 2016a). This blood-feeding activity is the main sign of haemonchosis, leading to anaemia, weakness and, frequently, to death (Besier et al., 2016b). In Tunisia, the prevalence of $H$. contortus in sheep and goats has recently been estimated at $17.0 \%$ and $33.6 \%$, respectively (Akkari et al., 2013).

The most commonly used method to control these gastrointestinal parasitic nematodes is based on the repeated use of chemical agents (Knox et al., 2012; Leathwick, 2012). However, the repeated use of anthelmintics has several disadvantages and limitations, including high toxicity, high cost, the presence of residues in the environment and in consumer products, and the increasing resistance of parasites to drugs (Chartier \& Hoste, 1994; Waller, 2006; Peña-Espinoza et al., 2014; Van den Brom et al., 2015). In this context, searching for promising approaches to identify new natural candidates for parasitic control in sheep is important (Alonso-Díaz et al., 2010). In this regard, the present study focused on polyphenol-rich plants as a natural alternative to the classical anthelmintics.

Polyphenols have been considered to be the main active compounds responsible for anti-oxidant and biofunctional properties detected in many medicinal plants. Many in vitro and in vivo experiments have confirmed their protective activity against a multitude of human and animal conditions, such as allergy, inflammation and viral infections (Cutler et al., 2008; Carocho \& Ferreira, 2013). Phenolic compounds have been proposed to treat abomasal and intestinal parasitic nematodes (Hoste et al., 2006). Moreover, a relationship between polyphenols, flavonoids and tannins and the anthelmintic activity against $H$. contortus has been reported in a previous study (Akkari et al., 2016).

Chamomile (Matricaria recutita L.), an annual herbaceous plant of the Asteraceae family, is one of the most widely used and well-documented medicinal plants in the world (Gupta et al., 2010) and is generally regarded as safe (GRAS) because it neither contains toxic compounds nor represents any acute toxicity for humans and animals (Bradley, 1993; Tolouee et al., 2010). It has been used for centuries as a medicinal plant, mostly for a variety of illnesses related to inflammation of the skin, upper respiratory and gastrointestinal tract (Petronilho et al., 2012). It has several benefits for human and animal health such as antimicrobial, antidiarrhoeal, anti-oxidant, antispasmodic, anti-inflammatory, anti-allergic and antidepressant properties (McKay \& Blumberg, 2006; Cemek et al., 2010; Chandrashekhar et al., 2011; Al Bahtiti, 2012; Amsterdam et al., 2012; Sebai et al., 2014). Chamomile is known for its richness in phenolic compounds believed to be responsible for its biological activities (Gardiner, 2007; Guimarães et al., 2013). It contains phenolic compounds such as the flavonoids apigenin, quercetin, patuletin and luteolin, glucosides and coumarins (herniarin and umbelliferone) (Mann \& Staba, 1986; McKay \& Blumberg, 2006).

As far as could be ascertained, there is no published report in the literature on the anthelmintic activity of chamomile. The present study aimed to investigate the radical-scavenging activity of $M$. recutita L. flower extracts obtained using solvents of increasing polarity. Flower extracts were also tested for their anthelmintic effects against $H$. contortus from sheep. These activities were correlated with the phenolic content of the plant extracts.

\section{Materials and methods}

\section{Plant material and preparation of extracts}

Chamomile flowers were cultivated from the region of Beja (north-west of Tunisia, altitude $448 \mathrm{~m} ; 36^{\circ} 81^{\prime} \mathrm{N}$; $9^{\circ} 05^{\prime} \mathrm{E}$ ) during spring 2013 and identified by Mouhiba Ben-Naceur, the Professor of Taxonomy in the Higher Institute of Biotechnology of Beja-Tunisia. Chamomile flowers were separated and thoroughly rinsed in running tap water then air dried for 14 days. The flowers were then ground to a fine powder in an electric blender (Moulinex Ovatio 2, Serris, France) and finally stored at $4^{\circ} \mathrm{C}$ until extraction.

Extracts were prepared by dissolving $100 \mathrm{~g}$ of powdered plant material in $500 \mathrm{ml}$ of extraction solvent with increasing polarity (water, methanol, chloroform and hexane). After $24 \mathrm{~h}$ of maceration at room temperature $\left(20-25^{\circ} \mathrm{C}, 3 \times 500 \mathrm{ml}\right)$ in the dark, to prevent light degradation, tested extracts were collected and filtered three times using Whatman No. 1 paper, then a rotary vacuum evaporator at $40^{\circ} \mathrm{C}$ was used in order to remove the solvent, and the aqueous filtrate was lyophilized using a lyophilizer.

\section{Plant extract analysis}

Concentrations of total polyphenols, flavonoids and tannins in flower extracts of $M$. recutita were determined by colorimetric methods.

\section{Total phenolic content}

Total phenolic content was determined by colorimetry using the Folin-Ciocalteu reagent (FCR) according to the method described by Singleton et al. (1999). An aliquot of $100 \mu \mathrm{l}$ of each tested extract was added to $500 \mu \mathrm{l}$ of FCR previously diluted in water $(1 / 10)$. A total volume of $4 \mathrm{ml}$ of $\mathrm{Na}_{2} \mathrm{CO}_{3}$ solution was then added to the mixture and mixed thoroughly before incubation for $15 \mathrm{~min}$ at room temperature. The absorbance versus a prepared blank was measured at $765 \mathrm{~nm}$. Total phenolic content was expressed as $\mathrm{mg}$ gallic acid equivalents/g dry weight (mg of GAE/g DW) using a calibration curve with gallic acid. The calibration curve range was $50-200 \mathrm{mg} / \mathrm{ml}$. Triplicate measurements were performed for all samples.

\section{Total flavonoid content}

Total flavonoid content was measured by the colorimetric method using aluminium ion $\mathrm{Al}^{3+}$ (Bahorun et al., 1996). To each extracted sample, $1.5 \mathrm{ml}$ of $\mathrm{AlCl}_{3}$ (2\%) solution were added. The mixture was then shaken thoroughly before incubation for $10 \mathrm{~min}$ at room temperature. The absorbance versus a prepared blank was measured at 367 $\mathrm{nm}$. Total flavonoid content was expressed as mg quercetin equivalents/g dry weight (mg QE/g DW) through 
a previously established quercetin calibration curve. Concentrations ranged from 15 to $100 \mathrm{~g} / \mathrm{ml}$. Triplicate measurements were performed for all samples.

\section{Condensed tannin content}

In the presence of concentrated $\mathrm{HCl}$, condensed tannins were transformed by the reaction with vanillin to anthocyanins (Sun et al., 1998). Fifty microlitres of each sample extract, appropriately diluted, were mixed with $3 \mathrm{ml}$ of $4 \%$ methanol vanillin solution and $1.5 \mathrm{ml}$ of $\mathrm{HCl}$. After $15 \mathrm{~min}$, the absorbance was measured at $500 \mathrm{~nm}$. Condensed tannin contents were expressed as mg catechin equivalents/g dry weight (mg CE/g DW) through a calibration curve with catechin. The calibration curve range was $50-600 \mathrm{mg} / \mathrm{ml}$.

\section{Anti-oxidant activity evaluation}

The anti-oxidant activity of each tested extract was measured using free-radical scavenging activity by DPPH (2,2-diphenyl-1-picrylhydrazyl) and by ABTS (2,2-azinobis[3-ethylbenzthiazoline-6-sulphonic acid]) radical cation.

\section{Free-radical scavenging ability using a stable DPPH radical}

The free-radical scavenging activity of extracts was measured by DPPH using the method described by Gorinstein et al. (2004). A volume of $2.8 \mathrm{ml}$ solution of DPPH in methanol $(0.1 \mathrm{~mm})$ was added to $0.2 \mathrm{ml}$ of each extract sample in methanol at different concentrations $(1.56,3.12,6.25,12.50,25.00,50.00$ and $100.00 \mu \mathrm{g} / \mathrm{ml})$, incubated in a dark room for $30 \mathrm{~min}$, then the absorbance was measured at $517 \mathrm{~nm}$. Radical scavenging activity was calculated using the following equation: Scavenging effect $=\left[\left(A_{0}-A_{1}\right) / A_{0}\right] \times 100$, where $A_{0}$ is the absorbance of the control and $A_{1}$ is the absorbance in the presence of the sample. The extract concentration providing $50 \%$ inhibition $\left(\mathrm{IC}_{50}\right)$ was calculated from the plot of inhibition percentage against extract concentration. Tests were carried out in triplicate.

Free-radical scavenging ability using a stable ABTS radical cation The free-radical scavenging activity was determined by the ABTS radical cation decolourization assay described by Siddhuraju (2006). ABTS was dissolved in water to a 7 $\mathrm{mm}$ concentration. ABTS radical cation $\left(\mathrm{ABTS}^{+}\right)$was produced by reacting ABTS stock solution with $2.45 \mathrm{~mm}$ potassium persulphate and was kept in a dark room at room temperature for $12-16 \mathrm{~h}$ before use. The $\mathrm{ABTS}^{+}$ was diluted to the absorbance of $0.70 \pm 0.02$ and stocked for off-line and on-line assays. A volume of $1 \mathrm{ml}$ of each diluted tested extract at different concentrations (1.56, $3.12,6.25,12.50,25.00,50.00$ and $100.00 \mathrm{~g} / \mathrm{ml}$ ) was added to $3 \mathrm{ml}$ of $\mathrm{ABTS}^{+}$solution and kept in a dark place at room temperature for $60 \mathrm{~min}$. The absorbance was measured at $734 \mathrm{~nm}$. The scavenging capacity was calculated as $\left[\left(A_{0}-\mathrm{Ab}\right) / A_{0}\right] \times 100$, where $\mathrm{Ab}$ is the absorbance in the presence of the sample, and $A_{0}$ refers to the absorbance of $\mathrm{ABTS}^{+}$without sample. The extract concentration providing $50 \%$ inhibition $\left(\mathrm{IC}_{50}\right)$ was calculated from the plot of inhibition percentage against chamomile extract concentration. All tests were performed in triplicate. For both DPPH and ABTS assays, the same procedure was repeated with a synthetic anti-oxidant - ascorbic acid - as positive control. Anti-oxidative capacities of the extracts were compared with those of ascorbic acid.

\section{In vitro anthelmintic assays}

The anthelmintic efficacy tests of chamomile extracts on $H$. contortus were performed using two different procedures. For each assay, the eggs or adult stages were obtained from faeces and abomasum of Barbarine donor lambs experimentally infected by oral administration of a pure aqueous suspension of $6000 \mathrm{H}$. contortus third-stage larvae (L3), according to the World Association for the Advancement of Veterinary Parasitology (WAAVP) guidelines (Coles et al., 1992).

\section{Egg-hatch assay}

Freshly collected eggs were incubated with different extracts in quadruplet. Dried flower extracts of M. recutita were used as a test treatment. Untreated eggs in phosphate-buffered saline (PBS) with dimethyl sulphoxide (DMSO) $(0.5 \%)$ solution were used as a negative control. Albendazole reference drug $(99.8 \%$ pure standard reference, Médivet, SA, Tunisia) was dissolved in DMSO and diluted at three concentrations $(0.25,0.50$ and $1.00 \mu \mathrm{g} / \mathrm{ml}$ ); eggs treated with the different concentrations of albendazole served as positive controls. For each extract concentration, approximately 200 eggs in $1 \mathrm{ml}$ of PBS were placed in each test tube. Sample extracts at different concentrations $(8.0,4.0,2.0,1.0,0.5$ and $0.25 \mathrm{mg} / \mathrm{ml})$ in $1 \mathrm{ml}$ PBS with DMSO $(0.5 \%)$ were used. After incubation for $48 \mathrm{~h}$ at $27^{\circ} \mathrm{C}$, egg hatching was stopped by adding Lugol's iodine solution. The numbers of L1 larvae and eggs per well were counted under a dissecting microscope at $40 \times$ magnification. The percentage of hatched eggs was determined using the ratio: number of $\mathrm{L} 1 \times 100 /$ (number of eggs + number of L1).

\section{Adult worm motility assay}

This test was performed according to HounzangbeAdote et al. (2005). Adult worms were collected from a lamb, at week 6 after experimental infection. Immediately after being slaughtered, the abomasum was removed, opened and placed at $37^{\circ} \mathrm{C}$ in $0.9 \%$ sodium chloride solution. The collected parasites were then washed and kept in PBS solution. Eight actively moving worms were placed in Petri dishes filled with 8.0, 4.0, 2.0 and $1.0 \mathrm{mg} / \mathrm{ml}$ of $M$. recutita extracts in PBS with DMSO $(0.5 \%)$, in a volume of $3 \mathrm{ml}$. Albendazole dissolved in DMSO then in PBS at a final concentration of $1 \mathrm{mg} / \mathrm{ml}$ was used as a positive control. PBS with DMSO $(0.5 \%)$ was used as a negative control. All the tests were performed in triplicate. Inhibition of worm motility was the criterion of anthelmintic activity. The required delays for worm paralysis and/or complete immobility were recorded at $0,1,2,4,6$ and $8 \mathrm{~h}$. To test if the worms could recover their motility after incubation for $8 \mathrm{~h}$, they were washed with distilled water and resuspended in PBS for $30 \mathrm{~min}$. Worm death was ascertained by the absence of motility during an observation period of 5-6s. The immobility index was calculated as follows: 
Table 1. Extract yields, polyphenolic content and effect of Matricaria recutita extracts on free-radical scavenging capacity and egg-hatching activity.

\begin{tabular}{|c|c|c|c|c|c|c|c|}
\hline \multirow[b]{2}{*}{ Extract samples } & \multirow[b]{2}{*}{$\begin{array}{c}\text { Extract } \\
\text { yield (\%) }\end{array}$} & \multicolumn{3}{|c|}{ Polyphenolic content } & \multicolumn{2}{|c|}{ Radical scavenging activity } & \multirow{2}{*}{$\begin{array}{l}\begin{array}{c}\text { Anthelmintic } \\
\text { activity }\end{array} \\
\text { Egg hatching } \\
\mathrm{IC}_{50}(\mathrm{mg} / \mathrm{ml})\end{array}$} \\
\hline & & $\begin{array}{l}\text { TP (mg GAE/g } \\
\text { DW) }\end{array}$ & $\begin{array}{c}\mathrm{TF}(\mathrm{mg} \mathrm{QE} / \mathrm{g} \\
\mathrm{DW})\end{array}$ & $\begin{array}{c}\mathrm{CT}(\mathrm{mg} \mathrm{CE} / \mathrm{g} \\
\mathrm{DW})\end{array}$ & $\begin{array}{c}\mathrm{DDPH} \mathrm{IC}_{50} \\
(\mu \mathrm{g} / \mathrm{ml})\end{array}$ & $\begin{array}{l}\text { ABTS IC }_{50} \\
(\mu \mathrm{g} / \mathrm{ml})\end{array}$ & \\
\hline Aqueous extract & 11.18 & $24.93 \pm 0.41$ & $18.37 \pm 1.58$ & $7.42 \pm 0.08$ & 1.23 & 1.38 & 2.559 \\
\hline $\begin{array}{l}\text { Methanolic } \\
\text { extract }\end{array}$ & 10.54 & $42.12 \pm 2.30$ & $28.45 \pm 0.19$ & $7.42 \pm 0.33$ & 1.18 & 1.19 & 1.523 \\
\hline $\begin{array}{l}\text { Chloroformic } \\
\text { extract }\end{array}$ & 9.12 & $5.34 \pm 0.73$ & $12.54 \pm 0.19$ & $0.70 \pm 0.04$ & 45.89 & 44.86 & 5.347 \\
\hline Hexanic extract & 8.22 & $1.67 \pm 0.20$ & $4.64 \pm 0.29$ & $0.37 \pm 0.04$ & 69.72 & 64.36 & - \\
\hline
\end{tabular}

$\mathrm{TP}$, Total phenolic content expressed as mg gallic acid equivalents/g dry weight (mg GAE/g DW); TF, total flavonoid content expressed as $\mathrm{mg}$ quercetin equivalents/g dry weight (mg QE/g DW); TC, condensed tannin contents expressed as mg catechin equivalents/g dry weight (mg CE/g DW); DDPH, 2,2-diphenyl-1-picrylhydrazyl; ABTS, 2,2-azino-bis(3-ethylbenzthiazoline-6-sulphonic acid); IC ${ }_{50}$, value of concentration causing $50 \%$ inhibition of the activity.

Immobility index $(\%)=100 \times($ number of dead worms per Petri dish/total number of worms per Petri dish).

\section{Statistical analysis}

The statistical analysis was performed using the SPSS 10.0 software package for Windows (SPSS Inc., Chicago, Illinois, USA). SigmaPlot 12.0 (Systat Software Inc., San José, California, USA) was used to calculate the $\mathrm{IC}_{50}$ for ABTS, DPPH and egg-hatch inhibition.

Regression was used for evaluation of the doseresponse relationship using Minitab $^{\circledR}$ Release 14 (Minitab SARL (France) www.minitab.com). The result of the worm motility inhibition was expressed as mean \pm standard error of mean (SEM). The results of $\mathrm{IC}_{50}$ for egg-hatching inhibition were assessed statistically using analysis of variance (ANOVA) and complemented by multiple comparisons of means by the SNK test (Student-Newman-Keuls). Spearman's correlation coefficients were calculated between anti-oxidant capacity and anthelmintic effects versus polyphenolic content, between DDPH and ABTS assays, DDPH and egg-hatching assays and, finally, between ABTS and egg-hatching assays of tested extracts (SPPS 10.0 software). Means of DDPH, ABTS scavenging activities and anthelmintic efficacy were compared by Wilcoxon test (SPSS 10.0 software). A probability of 0.05 was used as the threshold for statistical significance.

\section{Results}

\section{Extract yields}

The highest percentage yield of extraction of $M$. recutita was in the aqueous extract $(11.18 \%)$ while yields of the methanolic, chloroformic and hexanic extracts were $10.54,9.12$ and $8.22 \%$, respectively (table 1 ).

\section{Total phenolic, flavonoid and condensed tannin contents}

Phytochemical screening revealed the presence of polyphenols, flavonoids and condensed tannins in all the tested extracts. Their amounts varied according to the nature of the extract.The highest concentration was found in the methanolic extract $(42.12 \pm 2.30,28.45 \pm 0.19$ and $7.42 \pm 0.33 \mathrm{mg} / \mathrm{g} \mathrm{DW}$, respectively), while the chamomile hexanic extract gave the lowest amount of these compounds $(1.67 \pm 0.20,4.64 \pm 0.29$ and $0.37 \pm 0.04 \mathrm{mg} / \mathrm{g}$ DW, respectively) (table 1 ).

\section{Anti-oxidant activity}

The radical scavenging activity of chamomile extracts and ascorbic acid increased significantly in a dosedependent manner (fig. 1). Inhibitory concentrations for methanol and aqueous extract $\left(\mathrm{IC}_{50}\right)$ were 1.19 and 1.38$\mu \mathrm{g} / \mathrm{ml}$, respectively, for ABTS and 1.18 and $1.23 \mu \mathrm{g} / \mathrm{ml}$, respectively, for DPPH scavenging activities. These two extracts showed important anti-oxidant activity, being close to ascorbic acid $\left(\mathrm{IC}_{50}=1.16\right.$ and $1.17 \mu \mathrm{g} / \mathrm{ml}$ for DPPH and ABTS scavenging activities, respectively) (table 1, fig. 1).

The comparison between DPPH and ABTS scavenging activities showed that there was a statistically significant correlation with aqueous, methanolic, chloroformic and hexanic extracts $(r=0.915,0.758,0.948$ and 0.915 , respectively; $P<0.01$ ) (table 2 ). Also, a high positive correlation was observed between total polyphenols, flavonoids and condensed tannins with scavenging of DPPH (0.764, 0.722 and 0.731 , respectively; $P<0.01)$ and ABTS radicals $(0.722,0.752(P<0.01)$ and $0.604(P<0.05)$, respectively $)$ (table 3).

\section{In vitro anthelmintic assays}

\section{Egg-hatch assay}

Methanolic and aqueous extracts from chamomile showed higher inhibitory effects on egg hatching $\left(\mathrm{IC}_{50}=1.523,2.559 \mathrm{mg} / \mathrm{ml}\right.$, respectively) (table 1$)$. The inhibitory effect of the hexanic extract was the lowest, as it induced $42.06 \%$ egg-hatching inhibition at $8 \mathrm{mg} / \mathrm{ml}$ (fig. 2). Albendazole inhibited $91.75 \%$ of egg hatching at $1 \mu \mathrm{g} / \mathrm{ml}\left(\mathrm{IC}_{50}=0.1255 \mu \mathrm{g} / \mathrm{ml}\right)$. The maximum concentration required to induce total $(100 \%)$ egg-hatch inhibition for the methanolic extract was $4 \mathrm{mg} / \mathrm{ml}$ (table 1).

On the one hand, the results showed a high correlation between the inhibition of egg hatching and total polyphenols, flavonoids and tannins $(r=0.747,0.749$ and 0.818 , 

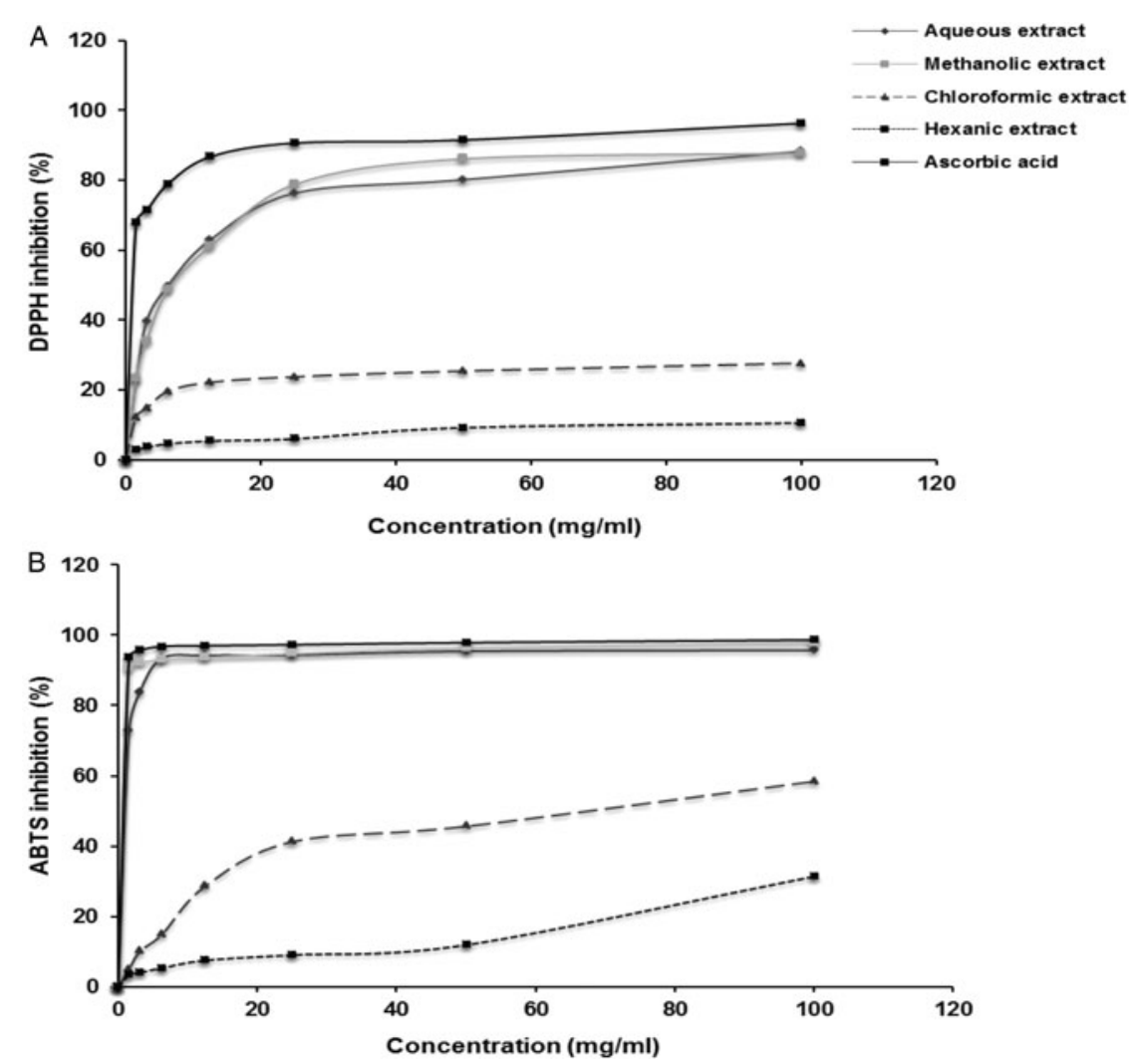

Fig. 1. Free-radical scavenging activities of aqueous, methanolic, chloroformic and hexanic extracts of Matricaria recutita and ascorbic acid measured by (A) DPPH and (B) ABTS methods.

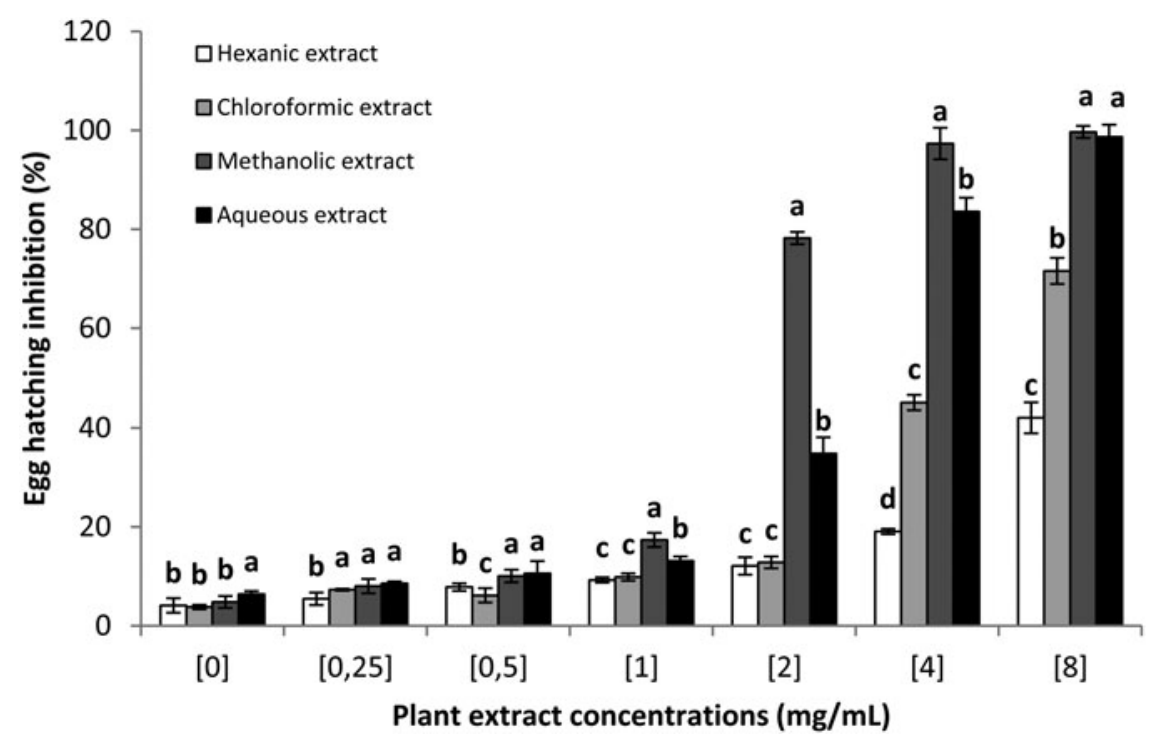

Fig. 2. Dose-dependent profile of the egg-hatching inhibition of Haemonchus contortus submitted to increasing concentrations of plant extract $(0,0.25,0.5,1,2,4,8 \mathrm{mg} / \mathrm{ml})$. Standard errors of the mean are shown on each bar. Values labelled with superscript letters (ad) are significantly different $(P<0.001), n=4$. 
Table 2. Pearson's correlation coefficient between DDPH and ABTS assays, DDPH and egg-hatching assays, and ABTS and egg-hatching assays of tested extracts of Matricaria recutita.

\begin{tabular}{|c|c|c|c|}
\hline \multirow[b]{2}{*}{ Extract samples } & \multicolumn{3}{|c|}{ Correlation coefficient } \\
\hline & $\begin{array}{l}\text { DDPH vs. } \\
\text { ABTS }\end{array}$ & $\begin{array}{l}\text { DDPH vs. egg } \\
\text { hatching }\end{array}$ & $\begin{array}{l}\text { ABTS vs. egg } \\
\text { hatching }\end{array}$ \\
\hline Aqueous extract & $0.915^{* *}$ & $0.701^{* *}$ & $0.874^{* *}$ \\
\hline $\begin{array}{l}\text { Methanolic } \\
\text { extract }\end{array}$ & $0.758^{* *}$ & $0.640^{* *}$ & $0.922^{* *}$ \\
\hline $\begin{array}{l}\text { Chloroformic } \\
\text { extract }\end{array}$ & $0.948^{* *}$ & $0.706^{* *}$ & $0.767^{* *}$ \\
\hline Hexanic extract & $0.915^{* *}$ & $0.813^{* *}$ & $0.747^{* *}$ \\
\hline
\end{tabular}

**, $P<0.01$.

respectively, $P<0.01$ ) (table 3 ). On the other hand, the inhibition of egg hatching was significantly correlated with scavenging of both DPPH $(r>0.640 ; P<0.01)$ and ABTS radicals $(r>0.747 ; P<0.01)$ in all tested extracts (table 2$)$.

\section{Adult worm motility assay}

All extracts produced in vitro showed dose-dependent activity on adult parasites. The methanolic extract, however, killed more worms than the other extracts at all concentrations tested $(P<0.05)$. After $8 \mathrm{~h}$, it induced $91.77 \%$ mortality at the highest concentration tested $(8 \mathrm{mg} / \mathrm{ml})$, while the aqueous extract induced only $75.05 \%$ mortality at the same concentration (table 4). There was $82.26 \%$ mortality of worms in albendazole within $8 \mathrm{~h}$ postexposure. However, the worms in the DMSO negative control solution showed neither paralysis nor mortality. Finally, no worm recovered motility in the PBS revival test.

\section{Discussion}

In this study, $M$. recutita flower extracts recovered using solvents of increasing polarity were examined for their anti-oxidant and anthelmintic activities.

First, the results of the phytochemical study showed that $M$. recutita was rich in polyphenols, flavonoids and condensed tannins. Their quantities were higher in methanolic and aqueous extracts compared to extracts in other organic solvents (chloroform and hexane). The phenolic contents of the tested extracts were higher than that of the decoction extract from Tunisian M. recutita (Sebai et al., 2015) and they were higher than those of the extracts of Brazilian chamomile tea and infusions (Guimarães

Table 3. Correlation coefficients of total phenolic, total flavonoid and condensed tannin contents versus DPPH, ABTS radical scavenging activity and egg-hatching inhibition of $M$. recutita extracts.

\begin{tabular}{lllc}
\hline & DDPH & ABTS & Egg hatching \\
\hline Total phenolic & $-0.764^{* *}$ & $-0.722^{* *}$ & $-0.747^{* *}$ \\
Total flavonoid & $-0.722^{* *}$ & $-0.752^{* *}$ & $-0.749^{* *}$ \\
Condensed tannin & $-0.731^{* *}$ & $-0.604^{*}$ & $-0.818^{* *}$ \\
\hline
\end{tabular}

**, $P<0.01 ; *, P<0.05$. et al., 2013; Zielinski et al., 2014). However, many other studies showed that ethanolic and aqueous extracts contain more phenolic compounds than the extracts tested in this study (Vinha et al., 2012; Alibabaei et al., 2014). This could be attributed to the geographic origin and the variety of chamomile (Sharafzadeh \& Alizadeh, 2011) as well as the climatic conditions and the extraction process (Papagiannopoulos et al., 2004; Sebai et al., 2015). Moreover, the extracting solvent has a prominent impact on the amount and nature of the compounds recovered, so the difference in phytochemical profile can modify the efficacy and the biological activity of the extract (Makris \& Kefalas, 2004; Naczk \& Shahidi, 2006; Sifaoui et al., 2014).

The results of this study are consistent with previous results from other studies, which confirmed the high concentration of phenolic compounds in chamomile (Guimarães et al., 2013; Mekinić et al., 2014). Many authors showed that polar solvents, especially methanol and ethanol, are more efficient in extracting these phenolic compounds because they have high polarity and good solubility (Roby et al., 2013; Formisano et al., 2015).

Beside the phytochemical composition, free-radical scavenging activity of different extracts was investigated by two methods: DPPH and ABTS. Results showed that all chamomile extracts were characterized by important antioxidant activities for both tests. Methanolic and aqueous extracts showed the best scavenging activity, with lower values compared to chloroformic and hexanic extracts as well as other plant extracts well known for their antioxidant properties (Kelebek et al., 2009; Zhao et al., 2011).

For all extracts, a significant and positive correlation between DPPH and ABTS tests was observed. Therefore, the current results highlight that total phenolic, total flavonoid and condensed tannin contents were positively correlated with both ABTS and DPPH radical assays. This means that the good anti-oxidant capacity of chamomile is mainly related to the high levels of polyphenols and flavonoids. This correlation was supported by many authors and is common among the majority of plants (Pyo et al., 2004; Hamad et al., 2010; Guimarães et al., 2013; Akkari et al., 2016). The findings of this study corroborate previous reports suggesting that phenols and flavonoids contained in chamomile methanolic extract strongly contribute to the anti-oxidant activity (Formisano et al., 2015). Recent findings suggest that especially quercetin (flavonol), chlorogenic acid, caffeic acid, p-coumaric acid and ferulic acid (phenolic acids) are the primary sources of anti-oxidant ability of chamomile methanolic extract, by scavenging free radicals such as the hydroxyl radical $(\mathrm{OH})$, which is the major cause of lipid peroxidation (Nováková et al., 2010; Roby et al., 2013).

Our results confirm the anthelmintic effect of chamomile extracts on $H$. contortus. Methanolic extract totally inhibited egg hatching at low concentration $(4 \mathrm{mg} / \mathrm{ml})$ compared to aqueous, chloroformic and hexanic extracts. These results confirm those of a previous study, in which the methanolic extract from Rubus ulmifolius inhibited $95.66 \%$ of egg hatching at $4 \mathrm{mg} / \mathrm{ml}$ (Akkari et al., 2016). However, ethanolic extracts of Artemisia campestris and Thymys capitatus had good activity at a lower concentration $(2 \mathrm{mg} / \mathrm{ml}$ ) (Boubaker Elandolsi et al., 2013; Akkari et al., 2014). 
Table 4. In vitro anthelmintic efficacy of extracts of Matricaria recutita on Haemonchus contortus.

Mortality rate (\%) of Haemonchus contortus worms post-exposure to various treatments $($ mean \pm SEM $)$

\begin{tabular}{|c|c|c|c|c|c|c|c|c|}
\hline Treatment & $\mathrm{C}(\mathrm{mg} / \mathrm{ml})$ & $0 \mathrm{~h}$ & $1 \mathrm{~h}$ & $2 \mathrm{~h}$ & $4 \mathrm{~h}$ & $6 \mathrm{~h}$ & $8 \mathrm{~h}$ & PBS \\
\hline \multirow[t]{4}{*}{ Aqueous extract } & 1 & $0 \pm 0.0$ & $0 \pm 0.0$ & $0 \pm 0.0$ & $8.25 \pm 0.05$ & $10.87 \pm 0.15$ & $16.33 \pm 0.05$ & $0 \pm 0.0$ \\
\hline & 2 & $0 \pm 0.0$ & $0 \pm 0.0$ & $0 \pm 0.0$ & $19.37 \pm 0.15$ & $21.08 \pm 0.08$ & $34.15 \pm 0.03$ & $0 \pm 0.0$ \\
\hline & 4 & $0 \pm 0.0$ & $0 \pm 0.0$ & $0 \pm 0.0$ & $31.50 \pm 0.11$ & $35.26 \pm 0.09$ & $48.27 \pm 0.08$ & $0 \pm 0.0$ \\
\hline & 8 & $0 \pm 0.0$ & $0 \pm 0.0$ & $0 \pm 0.0$ & $35.29 \pm 0.11$ & $59.33 \pm 0.05$ & $75.05 \pm 0.02$ & $0 \pm 0.0$ \\
\hline \multirow[t]{4}{*}{ Methanolic extract } & 1 & $0 \pm 0.0$ & $0 \pm 0.0$ & $0 \pm 0.0$ & $12.71 \pm 0.01$ & $20.03 \pm 0.11$ & $33.45 \pm 0.07$ & $0 \pm 0.0$ \\
\hline & 2 & $0 \pm 0.0$ & $0 \pm 0.0$ & $0 \pm 0.0$ & $33.45 \pm 0.08$ & $39.63 \pm 0.07$ & $58.51 \pm 0.13$ & $0 \pm 0.0$ \\
\hline & 4 & $0 \pm 0.0$ & $0 \pm 0.0$ & $0 \pm 0.0$ & $41.71 \pm 0.05$ & $58.91 \pm 0.02$ & $79.25 \pm 0.05$ & $0 \pm 0.0$ \\
\hline & 8 & $0 \pm 0.0$ & $0 \pm 0.0$ & $0 \pm 0.0$ & $50.12 \pm 0.07$ & $74.36 \pm 0.06$ & $91.77 \pm 0.06$ & $0 \pm 0.0$ \\
\hline \multirow[t]{4}{*}{ Chloroformic extract } & 1 & $0 \pm 0.0$ & $0 \pm 0.0$ & $0 \pm 0.0$ & $0 \pm 0.0$ & $2.37 \pm 0.11$ & $12.64 \pm 0.10$ & $0 \pm 0.0$ \\
\hline & 2 & $0 \pm 0.0$ & $0 \pm 0.0$ & $0 \pm 0.0$ & $7.46 \pm 0.06$ & $12.33 \pm 0.08$ & $19.25 \pm 0.05$ & $0 \pm 0.0$ \\
\hline & 4 & $0 \pm 0.0$ & $0 \pm 0.0$ & $0 \pm 0.0$ & $12.51 \pm 0.11$ & $27.33 \pm 0.03$ & $33.46 \pm 0.08$ & $0 \pm 0.0$ \\
\hline & 8 & $0 \pm 0.0$ & $0 \pm 0.0$ & $0 \pm 0.0$ & $16.52 \pm 0.07$ & $34.12 \pm 0.06$ & $48.07 \pm 0.07$ & $0 \pm 0.0$ \\
\hline \multirow[t]{4}{*}{ Hexanic extract } & 1 & $0 \pm 0.0$ & $0 \pm 0.0$ & $0 \pm 0.0$ & $0 \pm 0.0$ & $2.82 \pm 0.01$ & $8,48 \pm 0.09$ & $0 \pm 0.0$ \\
\hline & 2 & $0 \pm 0.0$ & $0 \pm 0.0$ & $0 \pm 0.0$ & $4.27 \pm 0.06$ & $6.39 \pm 0.05$ & $10.39 \pm 0.13$ & $0 \pm 0.0$ \\
\hline & 4 & $0 \pm 0.0$ & $0 \pm 0.0$ & $0 \pm 0.0$ & $8.52 \pm 0.09$ & $9.33 \pm 0.11$ & $12.56 \pm 0.01$ & $0 \pm 0.0$ \\
\hline & 8 & $0 \pm 0.0$ & $0 \pm 0.0$ & $0 \pm 0.0$ & $12.68 \pm 0.09$ & $18.36 \pm 0.07$ & $25.25 \pm 0.05$ & $0 \pm 0.0$ \\
\hline Albendazole $^{\mathrm{a}}$ & 1 & $0 \pm 0.0$ & $0 \pm 0.0$ & $0 \pm 0.0$ & $21.55 \pm 1.22$ & $71.96 \pm 1.22$ & $82.26 \pm 0.01$ & $0 \pm 0.0$ \\
\hline PBS with DMSO $0.5 \%^{\mathrm{a}}$ & & $0 \pm 0.0$ & $0 \pm 0.0$ & $0 \pm 0.0$ & $0 \pm 0.0$ & $0 \pm 0.0$ & $0 \pm 0.0$ & $0 \pm 0.0$ \\
\hline
\end{tabular}

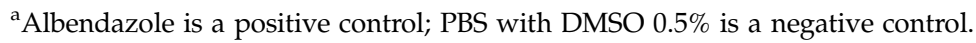

C, concentration.

The findings of the current study also provide evidence that chamomile extracts have significant impact on adult $H$. contortus, observed in terms of worm paralysis and/or death at different post-treatment intervals at even low concentrations. Previous studies revealed that $R$. ulmifolius exhibited significant activity at the same concentrations (Akkari et al., 2016); meanwhile, A. campestris and T. capitatus were active at lower concentrations (100\% inhibition at $2 \mathrm{mg} / \mathrm{ml}$ ) (Boubaker Elandolsi et al., 2013; Akkari et al., 2014).

Based on these results, a significant linear positive correlation between total polyphenols, flavonoids and tannin contents and anthelmintic activity was observed. Akkari et al. (2016) reported the same result with Rubus extracts. Many hypotheses have been proposed to explain the antiparasitic activity of these compounds, which are known to interfere with energy generation in parasites by uncoupling oxidative phosphorylation (Athnasiadou et al., 2001).

Tannins are known for their protein-binding ability, which can protect proteins from degradation in the rumen, and increase protein flow to the small intestine and amino acid absorption (Min et al., 2003; Waghorn \& McNabb, 2003; Hoste et al., 2006). Their antiparasitic activity on adults can be explained by their contact with the nematode's cuticle, buccal cavity, oesophagus and reproductive tract (Hoste et al., 2012; Martínez-Ortíz-deMontellano et al., 2013). Moreover, polyphenolic compounds might interfere with enzymes secreted or excreted by the worms in the local environment, or with enzymes involved in metabolic pathways that are essential for nematode functions (Athanasiadou et al., 2001).

The study of structural changes in adult $H$. contortus after in vitro exposure to medicinal plants has been the focus of several authors. Martínez-Ortíz-de-Montellano et al. (2013) studied two plants rich in tannins - sainfoin (Onobrychis viciifolia) and tzalam (Lysiloma latisiliquum) and showed that their effects were observed mainly in the cuticle, the cephalic region, the vulva and the anus of female worms. Microscopic observations showed longitudinal and transverse folds and thick crests in the cuticle. These lesions were observed either on the whole body or on patches along the whole body of the nematode, including the cephalic parts and the rest of the body, as well as the distal part of the worms. Thus, aggregates around the oral capsule, female vulva or anus have been observed and are similar under both in vivo and in vitro conditions.

The strong correlation between anti-oxidant and antiparasitic activity of chamomile can be explained by its rich flavonoid content. Interestingly, it has been suggested that anti-oxidant flavonoids might have anthelmintic activity (Ferreira, 2011) and anti-oxidant levels are also an indicator of flavonoids that can potentiate commercial anthelmintics. In fact, the anti-oxidant flavonoid quercetin is widely found in plants, and has been reported to increase the anthelmintic activity of moxidectin in lambs (Dupuy et al., 2003). Nevertheless, chamomile can be used to reduce parasitic burdens and to improve both animal production and health (Wangchuk, 2008).

Based on the results of the present study, chamomile extracts showed significant dose-dependent free-radical scavenging and in vitro anthelmintic activity against H. contortus, as ascertained by worm motility and egg-hatching inhibition. The presence of phenolic compounds, such as flavonoids and tannins, is particularly important for expressing various bioactivities. Chamomile may thus be exploited for the development of new natural anti-oxidant and anthelmintic agents. However, bio-guided purification will be necessary to isolate and purify bioactive compounds from chamomile flower extracts, to evaluate their in vivo activities and to study the structural changes in the worms by electron microscopy. This will be of great value to determine the mode of action of chamomile on the worms. 


\section{Acknowledgements}

We are grateful to Mr Sassi Limam, Mr Mohamed Jedidi, Mr Bechir Guesmi and Mr Tawfik Lahmar for their valuable technical assistance.

\section{Financial support}

This work received financial support from 'Laboratoire d'Epidémiologie d'Infections Enzootiques des Herbivores en Tunisie' (Ministère de l'enseignement supérieur, Tunisia).

\section{Conflict of interest}

None.

\section{Ethical standards}

The authors assert that all procedures contributing to this work comply with the ethical standards of the relevant national guides on the care and use of laboratory animals and have been approved by the institutional committee of the Institut Pasteur, Tunis.

\section{References}

Akhtar, M.S., Iqbal, Z., Khan, M.N. \& Lateef, M. (2000) Anthelmintic activity of medicinal plants with particular reference to their use in animals in the Indo-Pakistan subcontinent. Small Ruminant Research 38, 99-107.

Akkari, H., Jebali, J., Gharbi, M., Mhadbi, M., Awadi, S. \& Darghouth, M.A. (2013) Epidemiological study of sympatric Haemonchus species and genetic characterization of Haemonchus contortus in domestic ruminants in Tunisia. Veterinary Parasitology 193, 3118-3125.

Akkari, H., Rtibi, K., B'chir, F., Rekik, M., Darghouth, M.A. \& Gharbi, M. (2014) In vitro evidence that the pastoral Artemisia campestris species exerts an anthelmintic effect on Haemonchus contortus from sheep. Veterinary Research Communications 38, 249-255.

Akkari, H., Hajaji, S., B'chir, F., Rekik, M. \& Gharbi, M. (2016) Correlation of polyphenolic content with radical-scavenging capacity and anthelmintic effects of Rubus ulmifolius (Rosaceae) against Haemonchus contortus. Veterinary Parasitology 221, 46-53.

Al Bahtiti, N.H. (2012) Chemical analysis and biological activity of Jordanian chamomile extracts. Advanced Journal of Science and Technology 4, 22-25.

Alibabaei, Z., Rabiei, Z., Rahnama, S., Mokhtari, S. \& Rafieian-kopaei, M. (2014) Matricaria chamomilla extract demonstrates antioxidant properties against elevated rat brain oxidative status induced by amnestic dose of scopolamine. Biomedicine and Aging Pathology 4, 355-360.

Alonso-Díaz, M.A., Torres-Acosta, J.F.J., SandovalCastro, C.A. \& Hoste, H. (2010) Tannins in tropical tree fodders fed to small ruminants: a friendly foe? Small Ruminant Research 89, 164-173.

Amsterdam, J.D., Shults, J., Soeller, I., Mao, J.J., Rockwell, K. \& Newberg, A.B. (2012) Chamomile (Matricaria recutita) may have antidepressant activity in anxious depressed humans: an exploratory study. Alternative Therapies in Health and Medicine 18, 44-49.

Angulo-Cubillán, F.J., García-Coiradas, J.M.A. \& Cuquerella, M.C. (2010) Biological characterization and pathogenicity of three Haemonchus contortus isolates in primary infections in lambs. Veterinary Parasitology 171, 99-105.

Athanasiadou, S., Kyriazakis, I., Jackson, F. \& Coop, R. L. (2001) Direct anthelmintic effects of condensed tannins towards different gastrointestinal nematodes of sheep: in vitro and in vivo studies. Veterinary Parasitology 99, 205-219.

Bahorun, T., Gressier, B., Trotin, F., Brunet, C., Dine, T., Luyckx, M., Vasseur, J., Cazin, M., Cazin, J.C. \& Pinkas, M. (1996) Oxygen species scavenging activity of phenolic extracts from hawthorn fresh plant organs and pharmaceutical preparations. ArzneimittelForschung 46, 1086-1089.

Besier, R.B., Kahn, L.P., Sargison, N.D. \& Van Wyk, J.A. (2016a) The pathophysiology, ecology and epidemiology of Haemonchus contortus infection in small ruminants. Advances in Parasitology 93, 95-143.

Besier, R.B., Kahn, L.P., Sargison, N.D. \& Van Wyk, J.A. (2016b) Diagnosis, treatment and management of Haemonchus contortus in small ruminants. Advances in Parasitology 93, 181-238.

Boubaker Elandolsi, R., Akkari, H., Bchir, F., Gharbi, M., Mhadbi, M., Awedi, S. \& Darghouth, M.A. (2013) Thymus capitatus from Tunisian arid zone: chemical composition and in vitro anthelmintic effects on Haemonchus contortus. Veterinary Parasitology 197, 374-378.

Bradley, P. (1993) The British herbal compendium: A handbook of scientific information on widely used plant drugs. London, British Herbal Medicine Association.

Carocho, M. \& Ferreira, I.C.F.R. (2013) A review on antioxidants, prooxidants and related controversy: natural and synthetic compounds, screening and analysis methodologies and future perspectives. Food and Chemical Toxicology 51, 15-25.

Cemek, M., Yilmaz, E. \& Büyükokuroğlu, M.E. (2010) Protective effect of Matricaria chamomilla on ethanol-induced acute gastric mucosal injury in rats. Pharmaceutical Biology 48, 757-763.

Chandrashekhar, V.M., Halagali, K.S., Nidavani, R.B., Shalavadi, M.H., Biradar, B.S., Biswas, D. \& Muchchandi, I.S. (2011) Anti-allergic activity of German chamomile (Matricaria recutita L.) in mast cell mediated allergy model. Journal of Ethnopharmacology 137, 336-340.

Chartier, C. \& Hoste, H. (1994) Effect of anthelmintic treatments against digestive nematodes on milk production in dairy goats: comparison between high and low producing animals. Veterinary Research 25, 450-457.

Coles, G.C., Bauer, C., Borgsteede, F.H.M., Greerts, S., Klei, T.R., Taylor, M.A. \& Waller, P.J. (1992) World association for the advancement of veterinary parasitology (WAAVP) methods for the detection of anthelmintic resistance in nematodes of veterinary importance. Veterinary Parasitology 44, 35-44.

Cutler, G.J., Nettleton, J.A., Ross, J.A., Harnack, L.J., Jacobs, D.R. Jr, Scrafford, C.G., Barraj, L.M., Mink, P. 
J. \& Robien, K. (2008) Dietary flavonoid intake and risk of cancer in postmenopausal women: the Iowa women's health study. International Journal of Cancer 123, 664-671.

Dupuy, J., Larrieu, G., Sutra, J.F., Lespine, A. \& Alvinerie, M. (2003) Enhancement of moxidectin biovailability in lamb by a natural flavonoid: quercetin. Veterinary Parasitology 112, 337-347.

Ferreira, J.F.S. (2011) Artemisia species in small ruminant production: their potential antioxidant and anthelmintic effects. Available at www.ddr.nal.usda.gov/ bistream/10113/42326/1/IND44379380.pdf (accessed 15 April 2014).

Formisano, C., Delfine, S., Oliviero, F., Tenore, G.C., Rigano, D. \& Senatore, F. (2015) Correlation among environmental factors, chemical composition and antioxidative properties of essential oil and extracts of chamomile (Matricaria chamomilla L.) collected in Molise (south-central Italy). Industrial Crops and Products 63, 256-263.

Gardiner, P. (2007) Complementary, holistic, and integrative medicine: chamomile. Pediatrics in Review 28, 16-24.

Githiori, J.B., Athanasiadou, S. \& Thamsborg, S.M. (2006) Use of plants in novel approaches for control of gastrointestinal helminths in livestock with emphasis on small ruminants. Veterinary Parasitology 139, 308-320.

Gorinstein, S., Haruenkit, R., Park, Y.S., Jung, S.T., Zachwieja, Z., Jastrzebski, Z., Katrich, E., Trakhtenberg, S. \& Belloso, O. (2004) Bioactive compounds and antioxidant potential in fresh and dried Jaffa sweetie, a new kind of citrus fruit. Journal of the Science of Food and Agriculture 84, 1459-1463.

Guimarães, R., Barros, L., Dueñas, M., Calhelha, R.C., Carvalho, A.M., Santos-Buelga, C., Queiroz, M.J. \& Ferreira, I.C. (2013) Infusion and decoction of wild German chamomile: bioactivity and characterization of organic acids and phenolic compounds. Food Chemistry 136, 947-954.

Gupta, V., Mittal, P., Bansal, P., Khokra, S.L. \& Kaushik, D. (2010) Pharmacological potential of Matricaria recutita: a review. International Journal of Pharmaceutical Sciences and Drug Research 2, 12-18.

Hamad, İ., Erol-Dayi, Ö., Pekmez, M., Önay-Uçar, E. \& Arda, N. (2010) Antioxidant and cytotoxic activities of Aphanes arvensis extracts. Plant Foods for Human Nutrition 65, 44-49.

Hoberg, E.P., Kumsa, B., Pilitt, P.A. \& Abrams, A. (2010) Synlophe structure in Pseudomarshallagia elongate (Nematoda: Trichostrongyloidea), abomasal parasites among Ethiopian ungulates, with consideration of other morphological attributes and differentiation within the Ostertagiinae. Journal of Parasitology 96, 401-411.

Hoste, H., Jackson, F., Athanasiadou, S., Thamsborg, S.M. \& Hoskin, S.O. (2006) The effects of tannin-rich plants on parasitic nematodes in ruminants. Trends in Parasitology 6, 253-261.

Hoste, H., Martínez-Ortiz-De-Montellano, C., Manolaraki, F., Brunet, S., Ojeda-Robertos, N., Fourquaux, I., Torres-Acosta, J.F.J. \& Sandoval-Castro, C.A. (2012) Direct and indirect effects of bioactive tannin-rich tropical and temperate legumes against nematode infections. Veterinary Parasitology 186, 18-27.
Hounzangbe-Adote, M.S., Paolni, V., Fouraste, I., Moutairou, K. \& Hoste, H. (2005) In vitro effects of four tropical plants on three life-cycle stages of the parasitic nematode, Haemonchus contortus. Research in Veterinary Science 2, 155-160.

Kelebek, H., Selli, S., Canbas, A. \& Cabaroglu, T. (2009) HPLC determination of organic acids, sugars, phenolic compositions and antioxidant capacity of orange juice and orange wine made from a Turkish cv., Kozan. Microchemical Journal 91, 187-192.

Knox, M.R., Besier, R.B., Le Jambre, L.F., Kaplan, R.M., Torres-Acosta, J.F.J., Miller, J. \& Sutherland, I. (2012) Novel approaches for the control of helminth parasites of livestock VI: summary of discussions and conclusions. Veterinary Parasitology 186, 143-149.

Leathwick, D.M. (2012) Modelling the benefits of a new class of anthelmintic in combination. Veterinary Parasitology 186, 93-100.

Makris, D.P. \& Kefalas, P. (2004) Carob pods (Ceratonia siliqua L.) as a source of polyphenolic antioxidants. Food Technology and Biotechnology 42, 105-108.

Mann, C. \& Staba, E.J. (1986) The chemistry, pharmacology, and commercial formulations of chamomile. pp. 235-280 in Craker, L.E. \& Simon, J.E. (Eds) Herbs, spices, and medicinal plants: Recent advances in botany, horticulture and pharmacology. Phoenix Arizona, Oryx Press.

Martínez-Ortíz-de-Montellano, C., Arroyo-López, C., Fourquaux, I., Torres-Acosta, J.F.J., Sandoval-Castro, C.A. \& Hoste, H. (2013) Scanning electron microscopy of Haemonchus contortus exposed to tannin-rich plants under in vivo and in vitro conditions. Experimental Parasitology 133, 281-286.

McKay, D.L. \& Blumberg, J.B. (2006) A review of the bioactive and potential health benefits of chamomile tea (Matricaria recutita L.). Phytotherapy Research 20, 519-530.

Mekinić, I.G., Skroza, D., Ljubenkov, I., Krstulović, L., Možina, S.S. \& Katalinić, V. (2014) Phenolic acids profile, antioxidant and antibacterial activity of chamomile, common yarrow and immortelle (Asteraceae). Natural Product Communications 9, 17451753.

Min, B.R., Barry, T.N., Attwood, G.T. \& McNabb, W.C. (2003) The effect of condensed tannins on the nutrition and health of ruminants fed fresh temperate forages: a review. Animal Feed Science and Technology 106, 3-19.

Naczk, M. \& Shahidi, F. (2006) Phenolics in cereals, fruits and vegetables: occurrence, extraction and analysis. Journal of Pharmaceutical and Biomedical Analysis 41, 1523-1542.

Nováková, L., Vildová, A., Mateus, J.P., Gonçalves, T. \& Solich, P. (2010) Development and application of UHPLC-MS/MS method for the determination of phenolic compounds in chamomile flowers and chamomile tea extracts. Talanta 82, 1271-1280.

Papagiannopoulos, M., Wollseifen, H.R., Mellenthin, A., Haber, B. \& Galensa, R. (2004) Identification and quantification of polyphenols in carob fruits (Ceratonia siliqua L.) and derived products by HPLC-UV-ESI/ MSn. Journal of Agricultural and Food Chemistry 52, 3784-3791.

Peña-Espinoza, M., Thamsborg, S.M., Demeler, J. \& Enemark, H.L. (2014) Field efficacy of four 
anthelmintics and confirmation of drug-resistant nematodes by controlled efficacy test and pyrosequencing on a sheep and goat farm in Denmark. Veterinary Parasitology 206, 208-215.

Petronilho, S., Maraschin, M., Coimbra, M.A. \& Rocha, S.M. (2012) In vitro and in vivo studies of natural products: a challenge for their valuation. The case study of chamomile (Matricaria recutita L.). Industrial Crops and Products 40, 1-12.

Pyo, Y.H., Lee, T.C., Logendra, L. \& Rosen, R.T. (2004) Antioxidant activity and phenolic compounds of Swiss chard. Food Chemistry 85, 19-26.

Roby, M.H.H., Sarhan, M.A., Selim, K.A.H. \& Khalel, K.I. (2013) Antioxidant and antimicrobial activities of essential oil and extracts of fennel (Foeniculum vulgare L.) and chamomile (Matricaria chamomilla L.). Industrial Crops and Products 44, 437-445.

Sebai, H., Jabri, M.A., Souli, A., Rtibi., K., Selmi, S., Tebourbi, O., El-Benna, J. \& Sakly, M. (2014) Antidiarrheal and antioxidant activities of chamomile (Matricaria recutita L.) decoction extract in rats. Journal of Ethnopharmacology 152, 327-332.

Sebai, H., Jabri, M.A., Souli, A., Hosni, K., Rtibi, K., Tebourbi, O., El-Benna, J. \& Sakly, M. (2015) Chemical composition, antioxidant properties and hepatoprotective effects of chamomile (Matricaria recutita L.) decoction extract against alcohol-induced oxidative stress in rat. General Physiology and Biophysics 34, 263-275.

Sharafzadeh, S. \& Alizadeh, O. (2011) German and roman chamomile. Journal of Applied Pharmaceutical Science 1, 1-5.

Siddhuraju, P. (2006) The antioxidant activity and free radical-scavenging capacity of phenolics of raw and dry heated moth bean (Vigna aconitifolia) (Jacq.) Marechal seed extracts. Food Chemistry 99, 149-157.

Sifaoui, I., Lopez-Arencibia, A., Martin-Navarro, C.M., Chammem, N., Reyes-Batlle, M., Mejri, M., Lorenzo-Morales, J., Abderabba, M. \& Pinero, J.E. (2014) Activity of olive leaf extracts against the promastigote stage of Leishmania species and their correlation with the antioxidant activity. Experimental Parasitology 141, 106-111.

Singleton, V.L., Orthofe, R. \& Lamuela-Ravento, R.M. (1999) Analysis of total phenols and other oxidation substrates and antioxidants by means of FolinCiocalteu reagent. Methods in Enzymology 299, 152-178.

Sun, B.S., Leandro, M.C., Ricardo-da-Silva, J.M. \& Spranger, M.I. (1998) Separation of grape and wine proanthocyanidins according to their degree of polymerisation. Journal of Agricultural and Food Chemistry 46, 1390-1396.

Tolouee, M., Alinezhad, S., Saberi, R., Eslamifar, A., Zad, S.J., Jaimand, K., Taeb, J., Rezaee, M.B., Kawachi, M., Shams-Ghahfarokhi, M. \& Razzaghi-Abyaneh, M. (2010) Effect of Matricaria chamomilla L. flower essential oil on the growth and ultrastructure of Aspergillus niger van Tieghem. International Journal of Food Microbiology 139, 127-160.

Van den Brom, R., Moll, L., Kappert, C. \& Vellema, P. (2015) Haemonchus contortus resistance to monepantel in sheep. Veterinary Parasitology 209, 278-280.

Vinha, A.F., Soares, M.O., Castro, A., Santos, A., Oliveira, M.B.P.P. \& Machado, M. (2012) Phytochemical characterization and radical scavenging activity of aqueous extracts of medicinal plants from Portugal. European Journal of Medicinal Plants 2, 335-347.

Waghorn, G.C. \& McNabb, W.C. (2003) Consequences of plant phenolic compounds for productivity and health of ruminants. Proceedings of the Nutrition Society 62, 383-392.

Waller, P.J. (2006) From discovery to development: current industry perspectives for the development of novel methods of helminth control in livestock. Veterinary Parasitology 139, 1-14.

Wangchuk, P. (2008) Health impacts of traditional medicines and bio-prospecting: A world scenario accentuating Bhutan's perspective. Journal of Bhutan Studies 18, 116-134.

Zhao, H., Wang, Z., Cheng, C., Yao, L., Wang, L., Lu, W., Yang, X. \& Ma, F. (2011) In vitro free radical scavenging activities of anthocyanins from three berries. Journal of Medicinal Plants Research 5, 7036-7042.

Zielinski, A.A.F., Haminiuk, C.W.I., Alberti, A., Nogueira, A., Demiate, I.M. \& Granato, D. (2014) A comparative study of the phenolic compounds and the in vitro antioxidant activity of different Brazilian teas using multivariate statistical techniques. Food Research International 60, 246-254. 